\title{
Az új muzeológia megjelenése a budapesti múzeumokban
}

\author{
Szerzők: Bodnár Dorottya ${ }^{1}$ - Jászberényi Melinda² - Ásványi Katalin ${ }^{3}$
}

\begin{abstract}
A tanulmány egy 2016-os kutatás eredményeit foglalja össze, ami 15 különbözố méretú budapesti múzeum és kiállítóhely bevonásával készült. A kutatás többek között a múzeumok vezetốivel lefolytatott mélyinterjúkat és az intézmények kiállitásainak megfigyelését foglalja magában. A kutatás aspektusai közé tartoznak a célcsoportok, az interpretációs módszerek, az interaktivitás, a marketing, az önkéntesek bevonása stb. Az eredmények alapján feltételezhetó, hogy a látogatókat befolyásoló négy legfontosabb faktor a következó: központi elhelyezkedés, a múzeum történelmi épülete, a bemutatott téma általános jellege, valamint az interaktivitás szintje. Az eredmények elemzése az új muzeológia keretrendszerét vette alapul, egy olyan új paradigmáét, aminek a szempontjait a múzeumok üzemeltetése és fejlesztése kapcsán minden vezetônek figyelembe kellene vennie. A múzeumok felelösek a társadalom érzékenyitéséért a falaik között tárgyalt jelentôségteljes témák és az ott tárolt örökség értékét illetöen. Amennyiben nem fogadják el a fiatal generációk igényeihez és a XXI. század felgyorsult élettempójához igazodó szemléletmódot, úgy nem lesznek képesek a fenntartható múködéshez és a céljaik eléréséhez megfeleló számú (bevételt generáló) látogatót vonzani.
\end{abstract}

Kulcsszavak: új muzeológia, múzeum, interpretáció, interaktivitás.

\section{Irodalmi áttekintés és módszertan}

\section{1. ÚJ MUZEOLÓGIA}

A XX. század utolsó évtizedeiben a múzeumok megváltozott környezeti feltételekkel szembesültek, napjaink látogatóinak az igényei különböznek az előző nemzedékekben tapasztaltaktól. Az új muzeológia a hagyományos muzeológia hiányosságait kiküszöbölendő fejlődött ki, amely a múzeumok társadalomban betöltött szerepének a válto- elzárt intézményeknek vélték, amelyekre felesleges közpénzt költeni (HUDSON 1977). A múzeumok szerepét kizárólag egy szúk társadalmi csoport igényei határozták meg (HOOPER-GREENHILL 2000). Számos érzékeny vagy kevésbé fontos téma ezen oknál fogva a múzeumok falain kívül rekedt.

A XX. század végére a menedzsment és a kurátorok arra kényszerültek, hogy megváltoztassák a hozzáállásukat, valamint a színvonalról alkotott elképzelésüket. A múzeumok nehezen vették fel a versenyt más turisztikai attrakciókkal, a róluk kialakult imázsnak (unalmas, poros) változnia kellett (KIRSHENBLATT-GIMBLETT 1998). Az 1. ábra a koraitól az új muzeológiáig vezetó utat ábrázolja.

\section{Út a koraitól az új muzeológiáig}

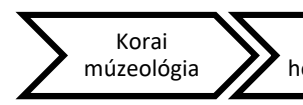

zásán alapul (McCALL - GRAY 2014). 1971-ben a múzeumokat elavult, elitista és a modern világtól

\footnotetext{
turisztikai osztályvezető, Nemzeti Örökségvédelmi Fejlesztési NKft.; PhD-hallgató, Budapesti Corvinus Egyetem, Marketing és Média Intézet Turizmus Tanszék, dorottya.bodnar@gmail.com

${ }^{2}$ egyetemi docens, Budapesti Corvinus Egyetem, Marketing és Média Intézet, Turizmus Tanszék, jaszberenyi@uni-corvinus.hu

3 egyetemi adjunktus, Budapesti Corvinus Egyetem, Marketing-, Média-

és Designkommunikáció Tanszék, katalin.asvanyi@uni-corvinus.hu
}

\subsubsection{Emberközpontúság}

A múzeumok a látogatók igényeivel egybecsengő fókuszváltásra kényszerültek, a jelenkori társadalom elvárásainak megfelelően a hangsúly a tárgyakról az emberekre helyeződött (SIMPSON 1996). “Egy múzeumi tárlóban elhelyezett tárgy önmagában nem bír jelentéssel. Tartalommal a szerző ruházza fel, aki lehet a kurátor, a régész, 
Lektorált tanulmányok

a történész vagy a látogató, aki rendelkezik azon 'kulturális kompetenciával', hogy felismerje és értelmezze a szakértő által hozzárendelt jelentéstartalmat" (WALSH 1992:32). A jelentéstartalommal való felruházás a modern múzeumok kulcstevékenysége, az örökséget nem definiálhatják fontosnak vagy kevésbé fontosnak. Ebből kifolyólag egy adott tárgy értelmezése egyre lényegesebbé válik, sőt az interpretáció magánál a tárgynál is érdekesebb lehet. „A kérdés nem az, hogy a tárgy vizuálisan érdekes-e, hanem hogy képes-e bármiféle érdeklődést kiváltani" (SMITH 2003:78). Napjaink társadalmának tagjai a tárgyak felhasználói, esetenként azonban a múzeumi alkotások megvalósításában is részt vesznek (SIMPSON 1996), ezt nevezik együtt alkotásnak (co-creation). A látogatók aktív szerepet játszanak, egyszerre irányítók és kurátorok is a kiállításokon (BLACK 2005, KREPS 2009). A látogatók érdeklődésének a felkeltése megkapó témákat feltételez, amelyek inspirálóan hatnak a kreativitásra, és ösztönzik a bevonódást. Ugyanakkor a múzeumok új szerepköre megkérdójelezhetó, amennyiben a klasszikus értékeket és a kurátorok mély szakértelmét figyelembe vesszük. "Ha a múzeum az emberek vélt elvárásait a kollekció elé helyezi, akkor a kiállított tárgyak elvesztik az értéküket és a jelentőségüket." (SMITH 2003:91). A hozzáállás változásával együtt a múzeumi szervezeteken belüli szerepek is módosultak. A komplex turisztikai élményt kínáló egyéb szolgáltatókhoz hasonlóan a vezetói funkciók itt is előtérbe kerültek. Másrészt a professzionális, tudományos háttér feltétlenül szükséges ezen intézmények hitelességéhez.

\subsubsection{Társadalmi összefüggés}

Társadalmi változásokat is érint a folyamat, amelynek keretében a múzeumlátogatók köre kiszélesedik. A múzeumok a „kulturális demokrácia" hajtómotorjaivá váltak (DCMS, 2006). Az emberek interdiszciplináris, érthetôbb kommunikációs stílust igényelnek (VERGO 1989). Tekintettel arra, hogy a múzeumok egyre szélesebb társadalmi csoportokat, akár korábban alul-reprezentált csoportokat (BLACK 2005) is megszólítanak, lehetôséget teremtenek még a társadalmi egyenlőtlenségekről és a diszkriminációról való párbeszéd folytatására is (SANDELL 2007), az ellentmondásos, feszültséget gerjesztó témákat nem kerülik egyértelmúen. A párbeszéd mellett az érzelmek legalább ennyire fontos szerepet játszanak, figyelembe véve, hogy egy múzeumi látogatás során a bevonódás csak akkor érhető el, ha a kiállítás érzéseket ébreszt, és nem csupán a szemlélódést teszi lehetôvé.

\subsubsection{Funkciók}

Kutatások bizonyítják, hogy a szabadidő és a szórakozás erôs múzeumlátogatási motivációt jelentenek (MOORE 1997, PACKER - BALLANTYNE 2002), amelyeket a tanulás, mint másodlagos motiváció követ. A múzeumok általános fókusza és ennek következtében fő funkciója szükségszerúen megváltozott, rekreációs intézményekké kell válniuk, amelyek a közönségre és annak az igényeire koncentrálnak (VERGO 1989). "A múzeumokra manapság erőteljes hatással bír a fogyasztói társadalom és a szórakoztatóipar, a múvészet és a kultúra látványos produkcióvá történő átalakítására törekszenek" (VERGO 1989).

A Múzeumok Nemzetközi Tanácsának (ICOM) 2007-es definíciója szerint "A múzeum egy állandó, non-profit intézmény a társadalom és annak fejlődése szolgálatában, ami a közösség elótt nyitva áll, összegyújti, megőrzi, kutatja, kommunikálja és kiállítja az emberiség és környezete kézzel fogható és eszmei örökségét tanítási, kutatási, valamint szórakoztatási céllal"'. A szórakoztatva tanítás (edutainment) áll a középpontban, mint az információ átadásának hatékony eszköze. Az ICOM saját állítását a következőkkel egészítette ki: "A múzeum fogalma a társadalmi fejlődéssel együtt megy át egy evolúciós folyamaton."

\subsection{LÁTOGATÓI IGÉNYEK VÁLTOZÁSA}

BODNÁR (2015) összefoglalja az örökségalapú attrakciók (például múzeumok) virtualizációjához vezetó utat. Az infokommunikációs technológiák (ICT), így a multimédiás berendezések vagy a mobil applikációk, különleges attrakciót nyújthatnak az élményközpontú turisztikai kereslet számára. Az ICT a turisztikai innovációk hajtómotorja, amely a múzeumok revitalizációjához különösképpen szükséges. A múzeumi fejlesztéseket illetően a kérdés nem az, hogy használjuk-e ezeket az eszközöket, hanem hogy miként tudjuk a hatásukat leginkább felerősíteni, mélyebb, gazdagabb, elmélyültebb látogatói élményt eredményezve (TOMIUC, 2014).

A múzeumokban a látogatók különféle dinamikus berendezésekkel (például audiovizuális és megfogható eszközök, interaktív térképek) találkozhatnak, amelyek kiegészítik vagy helyettesítik az elmúlt évtizedekben használt klasszikus, statikus eszközöket (makettek, fotók, leírások). A látogatók ingerküszöbét a hétköznapi élet alakítja ki, amelynek során, többnyire a nap 24 órájában, online kapcsolatban élnek. Médiatartalmat közvetító audiovizuális eszközök veszik őket körül, amelyek folyamatosan tágítják az említett határokat. 


\begin{abstract}
Általában véve a múzeumi menedzsment egyre inkább szembesül azzal, hogy a kereslet egyre gyengébb a klasszikus kulturális értékek iránt, ugyanakkor a technológiai innovációk, kulturális különbségek és extrémitások iránt jóval fogékonyabb. Ahhoz, hogy egy kiállítás üzenetei célba érjenek, többszintú interpretáció megvalósítására, valamint az eltérô célcsoportok igényeire és jellemzőire építő technikákra van szükség.

Ezzel párhuzamosan rövidebb ideig tudnak/ szándékoznak ugyanarra a tartalomra és az egész attrakcióra koncentrálni, gyorsan tekintik át a múzeumi feliratok és eszközök tartalmát, hatékonyan szûrve az óket érdeklő információkat.
\end{abstract}

\subsection{MÓDSZERTAN}

2016. február és május között a Budapesti Corvinus Egyetem harmadéves turizmus-vendéglátás alapszakos hallgatói felmérést végeztek 15 múzeum bevonásával, Jászberényi Melinda és Bodnár Dorottya doktorandusz felügyelete mellett. A múzeumok felkérése a Pulszky Társaság - Magyar Múzeumi Egyesület közremúködésével történt meg. A diákok 4-5 fős csoportokban dolgoztak. A primer kutatás eredményei szekunder forrásból származó adatokkal (látogatószám és annak öszszetétele az egyes intézményekben) együtt kerültek elemzésre.

A fő kutatási kérdés: Hogyan jelenik meg az új muzeológia gondolata a budapesti múzeumokban.

A kutatás a kényelmi mintavétel (convenience sampling) módszerére épül, a múzeumok elérhetőségük szerint kerültek be a felmérésbe. A lokációt illetóen a minta budapesti, a kiválasztott múzeumok és kiállítóhelyek több szempontból is különböznek, úgymint méret, elhelyezkedés, látogatószám, tematika. A módszertan lehetôvé teszi a téma feltáró jellegú kutatását.

A kutatás elsố részében végbemenő strukturált személyes megfigyelésekre természetes környezetben került sor, a múzeumi térben történő hallgatói megfigyelés formájában. Az elemzés célja a turisztikai környezet eltérő szemszögekből történô vizsgálata, a megfigyelés aspektusai világosan körülhatároltak. A megfigyelók szándékaival a múzeumok tisztában voltak, az intézmények hétköznapi múködését feltérképezték (például IT eszközök múködtetése), jóllehet személyközi interakciókat (tárlatvezetésen való részvétel) a hallgatók nem elemeztek.

A kutatás második részében a múzeumok vezető beosztású kollégáival (többek között múzeumvezetô, PR és marketing igazgató, vezetô múzeumpedagógus) való egyéni mélyinterjúk szerepeltek. Félig strukturált interjúk készültek, így a kérdések, témák adottak voltak, azonban a nyitott kérdések lehetőséget adtak arra is, hogy az interjúalany szabadon beszéljen gondolatairól.

Hasonló módszerrel jelen témában végzett kutatásról a szerzőknek nincs tudomása, így nem volt lehetőség más eredményekkel való közvetlen öszszevetésre.

\subsection{A KUTATÁS KORLÁTAI}

A múzeumok különféle technikákat alkalmaznak az adatgyújtésre. A látogatók száma és összetétele a hivatalos kulturális statisztikák mentén hasonlítható össze, amelyek nyilvánvalóan néhány mutatóra korlátozódnak. A kulturális statisztikák félrevezetóek lehetnek, tekintettel arra, hogy egy múzeum, mint ernyőszervezet alatt több kiállítási tér is múködhet, amelyekre vonatkozóan az adatok esetenként szétválasztva, máskor összesítve jelennek meg.

Egy diákok által végzett kvalitatív, interjúkra épüló kutatás általánosságban korlátokkal rendelkezik. Egy kvantitatív, kérdőívre épülő kutatás sokkal egzaktabb adatokat eredményezne, mindazonáltal kevesebb témakört ölelne fel, ráadásul a múzeumok menedzsereinek sem lenne lehetósége a véleményformálásra.

A kutatás anyagi korlátai okán nem volt lehetóség nagyobb számú véletlenszerú mintavételre, ezért a megállapítások fóként a kutatásban résztvevő múzeumokra érvényesek, általános érvényú következtetéseket belőlük levonni nem lehet.

\section{A kutatás eredményei - megfigyelés}

Az alfejezetben a megfigyelés eredményeit dolgoztuk fel, bizonyos témák esetében ezeket a mélyinterjúkban kapott válaszokkal egészítettük ki.

\subsection{LÁTOGATÓSZÁM - ELHELYEZKEDÉS, TÖRTÉNELMI ÉPÜLET, TEMATIKA, INTERAKTIVITÁS}

Turisztikai nézôpontból egy intézmény vagy kiállítás sikerességének fontos mércéjeként határozható meg az éves látogatószám és a teljes áron vett belépójegyek száma. A megfigyelt múzeumok között vannak nemzetközileg is jól ismert intézmények, mint a Magyar Nemzeti Galéria ${ }^{4}$, ami a mintában a legmagasabb látogatószámot produkálta 332.572 fővel, és kisebb múzeumok is, mint a helyi jelen-

\footnotetext{
${ }^{4}$ ÁSVÁNYI et al. (2017) mélyebben elemzi a Tripadvisor felületen található, a Magyar Nemzeti Galériára vonatkozó véleményeket, valamint jelen kutatás eredményeit a látogatói élmény szemszögéből vizsgálva.
} 
Lektorált tanulmányok

Múzeumok látogatószáma (2015), külföldi látogatók aránya és a négy kiemelt tényező

\begin{tabular}{|c|c|c|c|c|c|c|c|}
\hline & Múzeum neve & $\begin{array}{l}\text { Lá- } \\
\text { togató- } \\
\text { szám }\end{array}$ & $\begin{array}{c}\text { Külföldi } \\
\text { lá- } \\
\text { togatók } \\
\text { aránya } \\
\%\end{array}$ & $\begin{array}{l}\text { Történelmi } \\
\text { épület }\end{array}$ & $\begin{array}{c}\text { Központi } \\
\text { elhelyez- } \\
\text { kedés }\end{array}$ & $\begin{array}{l}\text { Általános } \\
\text { tematika }\end{array}$ & $\begin{array}{l}\text { Inter- } \\
\text { aktivitás }\end{array}$ \\
\hline \multirow{9}{*}{ 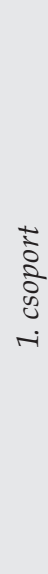 } & Magyar Nemzeti Galéria & 332572 & 30 & $\sqrt{ }$ & $\sqrt{ }$ & $\sqrt{ }$ & $x$ \\
\hline & Magyar Zsidó Múzeum és Levéltár ${ }^{1}$ & 205000 & 30 & $\sqrt{ }$ & $\sqrt{ }$ & $x$ & $x$ \\
\hline & Magyar Nemzeti Múzeum & 202714 & 25 & $\sqrt{ }$ & $\sqrt{ }$ & $\sqrt{ }$ & $\sqrt{ }$ \\
\hline & Magyar Természettudományi Múzeum & 162220 & 5 & $x$ & $x$ & $\sqrt{ }$ & $\sqrt{ }$ \\
\hline & Ludwig Múzeum & 111707 & 17 & $\sqrt{ }$ & $x$ & $\sqrt{ }$ & $x$ \\
\hline & Budapesti Történeti Múzeum & 99220 & 60 & $\sqrt{ }$ & $\sqrt{ }$ & $\sqrt{ }$ & $\sqrt{ }$ \\
\hline & Magyar Mezógazdasági Múzeum & 91130 & 7 & $\sqrt{ }$ & $\sqrt{ }$ & $\sqrt{ }$ & $\sqrt{ }$ \\
\hline & Iparmúvészeti Múzeum & 82484 & 62 & $\sqrt{ }$ & $x$ & $\sqrt{ }$ & $x$ \\
\hline & Petôfi Irodalmi Múzeum & 77092 & 8 & $x$ & $\sqrt{ }$ & $x$ & $\sqrt{ }$ \\
\hline \multirow{6}{*}{ 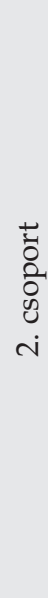 } & $\begin{array}{l}\text { Semmelweis Orvostörténeti Múzeum, } \\
\text { Könyvtár és Levéltár }\end{array}$ & 33998 & 18 & $x$ & $\sqrt{ }$ & $x$ & $x$ \\
\hline & $\begin{array}{l}\text { Óbudai Múzeum és Goldberger Textilipa- } \\
\text { ri Gyújtemény }\end{array}$ & 13936 & 0 & $x$ & $x$ & $x$ & $\sqrt{ }$ \\
\hline & $\begin{array}{l}\text { Magyar Kereskedelmi és Vendéglátóipari } \\
\text { Múzeum }\end{array}$ & 10971 & 4 & $x$ & $x$ & $x$ & $\sqrt{ }$ \\
\hline & $\begin{array}{l}\text { Országos Színháztörténeti Múzeum és } \\
\text { Intézet - Bajor Gizi Szinészmúzeum }\end{array}$ & 7029 & 1 & $x$ & $x$ & $x$ & $x$ \\
\hline & Budapest Galéria & 6000 & $\begin{array}{l}\text { nincs } \\
\text { adat }\end{array}$ & $x$ & $x$ & $x$ & $x$ \\
\hline & Bartók Béla Emlékház & 3000 & $\begin{array}{l}\text { nincs } \\
\text { adat }\end{array}$ & $\sqrt{ }$ & $x$ & $x$ & $x$ \\
\hline
\end{tabular}

Forrás: saját szerkesztés, EMMI kulturális statisztika

tőségú Óbudai Múzeum. A látogatószám alapján a múzeumokat két csoportra oszthatjuk. Az 1. csoport 9 intézményt tömörít, ezek egyenként évi 50.000-nél több látogatót vonzanak, a 2. csoportba 6 intézmény tartozik, amelyek évente kevesebb, mint 50.000 fós látogatottsággal bírnak. A cikk egészében az Emberi Erőforrások Minisztériuma kulturális statisztika - látogatószám adatai ${ }^{6}$ kerültek felhasználásra. Ezek az adatok nem tartalmazzák a múzeumokban szervezett kulturális programokon résztvevők számát, amely elérheti

\footnotetext{
${ }^{5} \mathrm{Az}$ 1. csoport 9 intézményt tömörít, ezek egyenként évi 50.000-nél több látogatót vonzanak, a 2. csoportba 6 intézmény tartozik, amelyek évente kevesebb, mint 50.000 fős látogatottsággal bírnak.

${ }^{6} \mathrm{http}$ ://kultstat.emmi.gov.hu/
}

vagy meghaladhatja a teljes látogatottság $20 \%$-át. A Budapest Galéria és a Bartók Béla Emlékház a Budapesti Történeti Múzeum részei, de nem szerepelnek a fenti kulturális statisztikában. A látogatószám adatokat az intézmények biztosították. A továbbiakban a minta összes eleme összefoglalóan „múzeumként” kerül említésre.

Egyes intézmények jelentôs, dijmentesen belépó látogatóforgalmat produkálnak (194/2000. (XI. 24.) Korm. rendeletben elóírtaknak megfelelóen), bizonyos esetekben ez az arány a $60-70 \%$-ot is elérheti; ez megnehezíti a fenntartható múködést. A legtöbb múzeumban a belépó díjat nem fizetők aránya 25-45\% körül mozog; ez az arány a Magyar Mezógazdasági Múzeumban a legalacsonyabb 
(10\%), azonban előfordul ennél sokkal magasabb, $70 \%$-os arány is (Óbudai Múzeum és Goldberger Textilipari Gyújtemény). A külföldről érkező látogatókat illetôen négy múzeum teljesít 25\% felett (Budapesti Történeti Múzeum, Magyar Nemzeti Múzeum, Magyar Zsidó Múzeum és Levéltár ${ }^{7}$, Magyar Nemzeti Galéria). Ez betudható a turisztikai szolgáltatókkal (például utazási irodák) való sikeres együttmúködésnek, de más faktorokon is múlhat, ahogy a későbbiekben kiderül.

A szekunder kutatás és a primer kutatás eredményeinek elemzése során négy tényező emelkedik ki a többi vizsgált szempont közül, amelyek potenciálisan a látogatószámot magyarázhatják. Egy múzeum sikeréhez hozzájárulhat, ha az a városközpontban, azon belül is a turisztikailag frekventált területen helyezkedik el (,,központi elhelyezkedés"). Szintén elónyt jelent, ha az intézmény maga történelmi, patinás épületben helyezkedik el, amely önmagában is látványos,

A Magyar Zsidó Múzeum 2015-ben 205.000 látogatót fogadott, habár a múzeum a Dohány utcai Zsinagógával együtt közösen üzemel. Kizárólag a Zsidó Múzeumba érkezők számát a müködtető nem dokumentálta. vonzerônek számít, ugyanakkor a belsô terei is különleges közeget biztosítanak egy gyújtemény elhelyezéséhez („történelmi épület"). Hozzájárul a látogatottsághoz, ha az adott múzeum által feldolgozott téma nem egy szúk területet fed le, nem korlátozódik egy szúk érdeklődésú célcsoportra, hanem átfogó jellegú, általánosabb, és ebből következóen gyúiteménye is nagyobb volumenú, jelentôsebb (,,általános tematika"). Az új muzeológia elveinek megfelelően szintén kiemelt sikertényezô egy modern múzeumban, ha a kiállításban jelentós az interaktív eszközök aránya, azok különböző célcsoportokra fókuszálnak és általánosan elérhetők a látogatók számára (,interaktivitás"). E négy faktor került elemzésre a vizsgálatban résztvevố múzeumok kapcsán. Ahogyan az 1. táblázatban látható, az interaktivitás értékelése a primer kutatáson alapul, a másik három faktor másodlagos adatokra épül.

\subsubsection{Központi elhelyezkedés}

A helyszínek elhelyezkedése a 2. ábrán nyomon követhetó. Az 50.000 fónél kevesebb látogatót vonzó

\section{Múzeumok elhelyezkedése Budapesten}

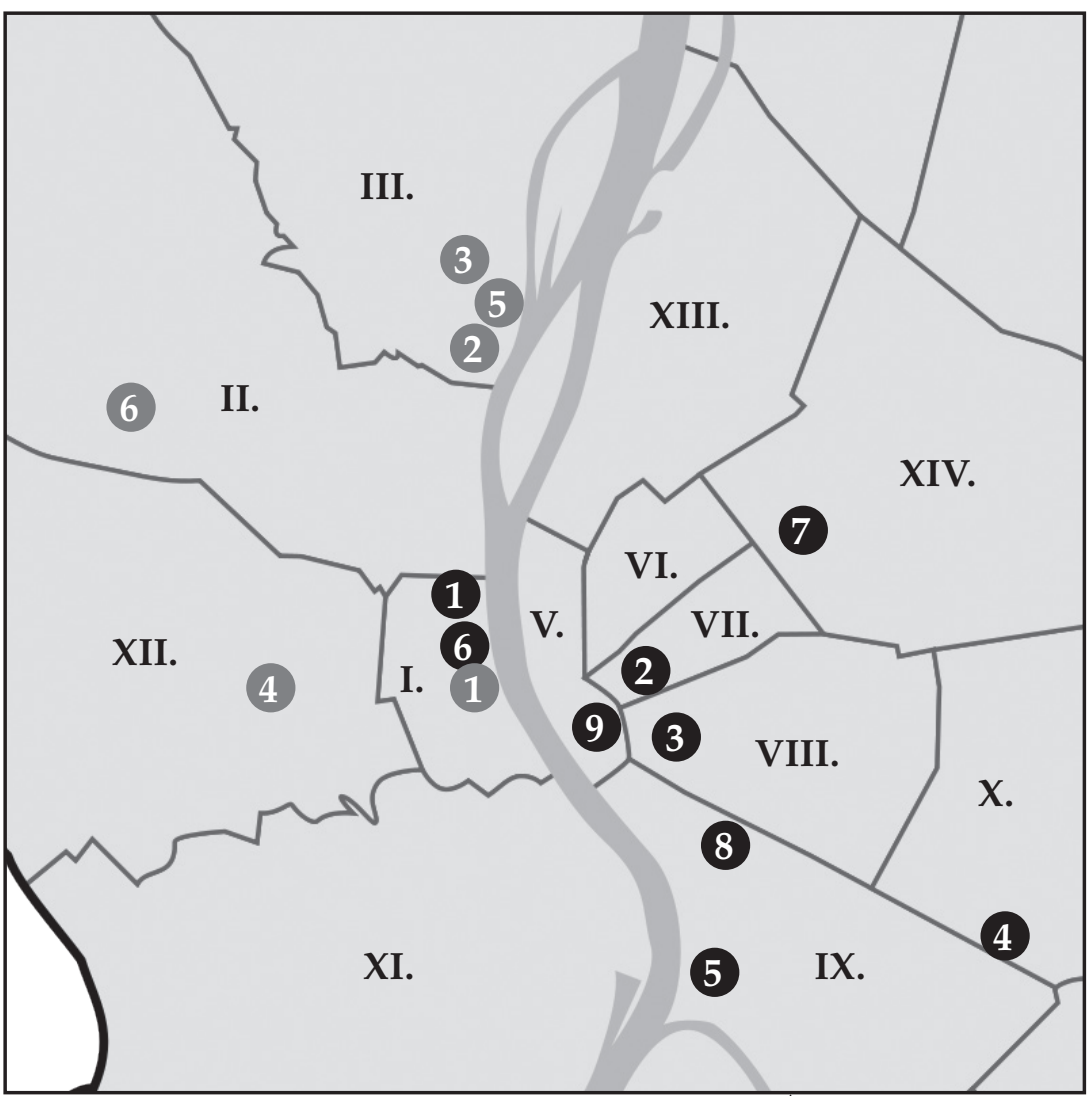

Forrás: Saját szerkesztés
50.000 fónél több látogató

(1) Magyar Nemzeti Galéria

2 Magyar Zsidó Múzeum és Levéltár

(3) Magyar Nemzeti Múzeum

(4) Magyar Természettudományi Múzeum

5 Ludwig Múzeum

6 Budapesti Történeti Múzeum

(7) Magyar Mezőgazdasági Múzeum

8 Iparmúvészeti Múzeum

9 Petőfi Irodalmi Múzeum

50.000 fó vagy annál kevesebb látogató

(1) Semmelweis Orvostörténeti Múzeum

(2) Óbudai Múzeum és Goldberger Textilipari Gyújtemény

(3) Magyar Kereskedelmi és Vendéglátóipari Múzeum

(4) Országos Színháztörténeti Múzeum és Intézet - Bajor Gizi Színészmúzeum

5) Budapest Galéria

6 Bartók Béla Emlékház 
Lektorált tanulmányok

múzeumok szürkével, az annál többet vonzóak feketével kerültek megjelölésre. A körök a belváros legnépszerúbb turisztikai zónáit mutatják.

Egyértelmúen látszik, hogy a leglátogatottabb múzeumok a belvárosban helyezkednek el; ezek közül néhány a népszerú, vezetett túrák részét képezi - buszos vagy más típusú városnézések. Egyes intézmények látogatószámát azonban nem határozza meg egyértelmúen az elhelyezkedés, belvárosi helyszín ellenére alacsony, avagy épp ellenkezóleg, külvárosi lokáció ellenére kiemelkedően magas látogatószámot regisztrál. Az alábbiakban elemzett tényezők ezen eltéréseket magyarázzák.

\subsubsection{Történelmi épület}

Néhány múzeum olyan történelmi (gyakran múemléki) épületben kapott helyet, amely önmagában is turisztikai vonzerôvel bír. A múzeumok imázsát ez a tényező erôsíti; tekintélyes épületekként, a város központjában állandó megállói a buszos és gyalogos túráknak. Ugyanakkor csak egy kis részük képes a falai közé „becsábítani” a turistákat, akik rendszerint csak kívülról készítenek képeket. Érdekes példája ennek a Magyar Mezőgazdasági Múzeum - ami a városligeti Vajdahunyad várában, a Hősök Tere mellett található - egyike a fóváros legnépszerúbb kültéri látványosságainak. A várkert ingyenesen látogatható, emiatt a múzeum maga nem tudott az arra sétáló több millió turistából profitálni, mielőtt a vár két tornyát is megnyitották volna a nagyközönség előtt - ez a látogatás elég rövid ahhoz, hogy a vezetett túrák szúken mért időkeretébe beleférjen. 2015-ben 91.130 ember kereste fel a múzeumot, további 45.000 ember pedig a tornyokba is feljutott. Az elhelyezkedést, mint faktort illetően egy fontos kivételként említhetô a modern, látványos, Duna-parti épületben múködő Ludwig Múzeum a maga 111.000 látogatójával. A kiállítás bizonyos mértékben interaktív, a gyújtemény jelentős, általános témát ölel fel, de a központon kívül esik. Az épületben múködik a Múvészetek Palotája, amellyel szoros az együttmúködés: a koncertek vendégei ingyenesen léphetnek be a múzeumba az előadás napjáig (ez évente nagyságrendileg 3.000 látogatót jelent).

\subsection{3. Általános tematika}

A múzeumban feldolgozott általános tematika és a múvészeti gyújtemény terjedelme (bizonyos esetekben 100.000-nél is több darab) további meghatározó tényezók a látogatószám szempontjából, hiszen nagyobb közönség számára jelent vonzerôt egy átfogóbb képzőmúvészeti, iparmúvészeti, történelmi kiállítás. Az 1. csoportban csak egy olyan intézmény van (a Petôfi Irodalmi Múzeum), ami szúkebb tematikára helyezi a hangsúlyt, tekintve hogy az állandó kiállítás Petőfi Sándorról, a legismertebb magyar költőről szól. Az idôszaki kiállításokon azonban helyet kapnak a magyar irodalmi élet további alakjai és témái is. Az orvoslástörténet, a színháztörténet vagy éppen az idegenforgalom és vendéglátás viszont túlságosan szúk témának bizonyulnak, még abban az esetben is, ha interaktív módon, modern szemléletben vannak tálalva.

\subsubsection{Interaktivitás}

A Petőfi Irodalmi Múzeum a centrumban található, egyike a leginkább interaktív és látogatóbarát intézményeknek a kutatásba bevont helyszínek közül. A Természettudományi Múzeum általános témával foglalkozik, kiemelkedó színvonalú interaktív kiállítása van, azonban a városközponton kívül helyezkedik el egy olyan épületegyüttesben, amelynek egy része történelmi, más része modern. Mindkét múzeumot leginkább magyarok látogatják, kiemelkedő népszerúségük miatt az 1 . csoportba sorolhatók.

A múzeumvezetôk több interjún is említették, hogy napjainkban egy kiállítás interaktív elemek nélkül nem igazán lehet sikeres. Számos múzeum rendelkezik valamiféle interaktív objektummal, ám ezek idóvel elavulttá válnak, még akkor is, ha nem elektromos eszközökról van szó. Az információtechnológia fejlődése olyan gyors, hogy ezek a berendezések legfeljebb 5-10 éven belül cserére szorulnak. Látogatói megítélés szempontjából az üzemképtelen eszközök pedig rosszabbak annál, mint ha egyáltalán nem volnának. Említett okoknál fogva egy kiállítás fejlesztése során a kurátoroknak különösen figyelni kell az IT alapú és a hagyományos, kézzel fogható eszközök arányára, amennyiben a minél jobb interaktív élmény átadását túzik ki célul. Források nélkül az egykor modernnek számító kiállítások is könnyen idejétmúlttá és érdektelenné válnak; bizonyos időközönként frissíteni szükséges óket. A megfogható (mú)tárgyak szintén roppant vonzóak lehetnek a látogatóknak, mivel a kezükbe vehetik és átérezhetik a történelmet; a jól megválasztott tárgyak generációkon át nyújthatnak különleges élményt a látogatóknak. A megfigyelés eredményeként megállapítható, hogy 15-ból kilenc múzeum használ megfogható objektumokat. Ezek egy része (mú) tárgy, más részük másolat, vagy egyéb tárgyak, például fajátékok, felépíthetó makettek. A látogatói élmény komplexitása érdekében célszerú mind az 5 érzékszervre hatni; a klasszikus látás-hallás kettôse mellett érdemes a szaglásra, tapintásra, ízlelésre is hangsúlyt fektetni, például fúszernövények 
illat alapján történő felismerését a Kereskedelmi és Vendéglátóipari Múzeumban. Maga az interpretációs módszer is unalmassá válhat, ha ugyanazt több intézményben is használják, ezért a kreativitás mindenekfelett álló szempont, mégis a felsorolt 15 múzeumban csak néhány egyedi eszközt említettek, például a kékfestő mintafák kipróbálását a Goldberger gyúiteményben.

A megfigyelés eredménye szerint a megfogható eszközök és az audio eszközök (hang, zene, beszéd) használata a leginkább elterjedt a résztvevő múzeumok körében. Fontos, hogy különbséget tegyünk a valódi interaktív elemek és az automaták között. Egy film vagy egy audio eszköz akkor interaktív - és így több egy egyszerû audiovizuális berendezésnél, melyet csak nézni/hallgatni lehet - ha a látogatónak van lehetôsége a folyamatba való bizonyos mértékú beavatkozásra.

A kutatási eredményekból látható, hogy a modern elektronikai eszközök fejlesztésére az intézményeknek rendszerint nem áll rendelkezésére anyagi forrás, éppen ezért korszerú IT-t csak az idôszakos kiállításokon használnak, mivel meggyőződésük szerint az állandó kiállításaikon nem képesek lépést tartani az IT eszközök fejlődésével. A múzeumok időszaki kiállításaikat elsősorban pályázati forrásból, illetve anyagi támogatásokból finanszírozzák, míg a jóval költségigényesebb, de állandó kiállítások hosszabb fejlesztési időt is igényelnének. Ez azért jelenthet problémát, mert az állandó kiállításoknak kellene a legvonzóbbaknak lenniük, hogy magas színvonalú, szilárd bázist nyújtsanak az intézményeiknek.

A 15-ből hat múzeum a következő, népszerúbb eszközöket alkalmazza: filmek, érintőképernyők, audio/visual guide eszközök, játékok (egyéni/csapat). A megfigyelt múzeumok között a legkevésbé használt interaktív eszközök közé tartoznak a mobil applikációk és a beöltözési lehetőségek (15ből kettố múzeum használja ezeket).

$\mathrm{Az}$ interaktív berendezésekre vonatkozó látogatói visszajelzések rendszerint azt mutatják, hogy az emberek nagyon kedvelik ezeket, mert javítják a látogatói élményt, illetve segítségükkel mélyebb tudásra tehetnek szert az adott témában. A múködtetők tapasztalatai szerint nem minden látogató bánik megfelelő módon az említett eszközökkel, emiatt gyakran meghibásodnak, állandó felügyeletet és karbantartást igényelnek.

Azok a múzeumok képesek magasabb látogatószámot elérni, amelyek esetén legalább két feltétel teljesül a négyből. Elmondható, hogy a történelmi épület és a központi fekvés lényeges faktorok, ugyanakkor ezek bármelyike helyettesíthetô interaktivitással vagy általános témaválasztással, mint a Magyar Természettudományi
Múzeum, a Ludwig Múzeum, az Iparmúvészeti Múzeum vagy a Petőfi Irodalmi Múzeum esetében látható. A Magyar Természettudományi Múzeumnak például évente több mint 162.000 látogatója van, ennek csak 5\%-a külföldi turista. Bár a városközponton kívül esik és az épületegyüttesnek csak egy része történelmi, mégis Budapest egyik leginteraktívabb, általános-átfogó témát feldolgozó kiállítása, ami rendkívül népszerúvé teszi a kisgyermekes magyar családok körében.

A látogatószámot befolyásoló másik fontos tényező a jól megválasztott időszaki kiállítás, például a 2014-es Robert Capa kiállítás a Magyar Nemzeti Múzeumban, amely 5 hónap alatt 42.000 látogatót generált. Az időszaki kiállítások tipikusan 2-6 hónapon belül cserélődnek - népszerúségtől, mérettôl és költségtől függôen. Az állandó kiállítások 5-10 évente változnak; egyes menedzserek állítása szerint azonban akár 40 évente vagy soha nem újulnak meg a pénzügyi források hiányában, annak ellenére, hogy frissítésük fontos lenne a látogatók ismételt megnyerése érdekében.

A látogatószám az egyes múzeumokban különböző irányban változott az utóbbi években; általános trendet nem lehet meghatározni. Egyes intézményekben a 2013-as adatokkal összehasonlítva óriási változások mentek végbe, melyeket külső tényezők ismeretében lehet megindokolni. A Semmelweis Orvostörténeti Múzeum látogatóinak a száma például 18.000-ről 33.000-re nôtt, amint a szomszédos - jelentős beruházásból megvalósított - történelmi Várkert Bazár megújult. A Kereskedelmi és Vendéglátóipari Múzeum viszont az elmúlt 10 évben kétszer kényszerült költözésre (2006-ban és 2011-ben), utoljára a belvárosból a városközpont határára. A látogatószám ennek folyományaként a 2013-as 43.000 főről 2015-re 10.900-ra apadt.

\subsection{CÉLCSOPORTOK}

Néhány kivételtől eltekintve a múzeumok helyesen, több nézôpontból is konzisztens módon határozzák meg a célközönségüket. A primer kutatáson belül a célcsoportra vonatkozó megfigyelés 4 fó témára fókuszált: a kommunikációra, a kiállításokon használt eszközökre, a tematikára és a tartalom/múzeumi jelzések nyelvezetére. Az elavultabb eszközökkel felszerelt kiállításokkal rendelkező, kevesebb interaktív elemet felvonultató múzeumok helyesen látják, hogy a közönségük a szenior korosztály tagjai és a szakmai látogatók közül kerül ki. S bár szinte az összes intézmény kifejezte abbéli szándékát, hogy a közösségi médián keresztül a fiatalokat hatásosabban szólítsa 
Lektorált tanulmányok

meg, fontos szembenézni a ténnyel, hogy megfeleló kínálat híján (alkalmazott eszközök, berendezések, téma, megfeleló interpretáció, nyelvezet) a múzeumok nem tudják sikeresen kiszolgálni e célcsoport igényeit.

A célcsoportokra vonatkozó ismertebb trendek visszaköszöntek a kutatásból: diák- és nyugdíjas csoportok rendszerint hét közben, egyéni látogatók általában a hétvégén keresik fel a múzeumokat nagyobb számban. A 14 évesnél fiatalabb korosztály tagjai gyakori látogatóknak számítanak, figyelmük felkelthetô és részt vesznek múzeumpedagógiai foglalkozásokon; ellenben "a középiskolások többségükben elutasítók, semmivel sem lehet őket becsábítani" - állította az egyik menedzser. Az egyetemi évek alatt ismét nyitottabbá válva a 20-30 év közötti fiatal felnóttek ugyancsak érdeklődőek. "A fiatal felnőttek életmódja döntó tényezô, amennyiben múveltek, érdeklódnek a kulturális programok iránt és szívesen járnak el otthonról, illetve amennyiben a szórakozás többet jelent számukra a bulizásnál" - közölte a fent említett menedzser hölgy. A Ludwig Múzeum kitúnik a többi közül azzal, hogy célközönsége tudatosan jól körülhatárolt: egy tipikus Ludwigos 28 éves, felsőfokú végzettséggel rendelkező nô (FEHÉR 2014, BODNÁR et al. 2015).

A menedzserek fele azonban megemlítette, hogy nem határoznak meg célcsoportokat, mivel a múzeumoknak képeseknek kéne lenniük a gyújteményük mindenki számára fogyasztható tartalmúvá alakítására. Egy haladó szellemú igazgató megjegyezte "Magyarországon a múzeumok még nem gondolkodnak célcsoportokban, mivel nem engedhetjük meg magunknak azt, hogy sajátos érdeklődésú csoportokra szabjunk kiállításokat". Némely kurátor látszólag "önmaga számára készít kiállításokat", a látogatók igényeinek mellózésével, mivel a tárlatok szakmai elismerése ugyancsak fontos az intézményeknek.

Bár a múzeumok különféle kulturális programokat szerveznek, amik nagymértékben növelhetik a látogatószámot és szélesíthetik a célközönséget, illetve különféle jövedelemtermeló tevékenységeket is folytatnak (például termek bérbeadása), azonban ezek még mindig kevéssé járulnak hozzá a gazdasági fenntarthatósághoz. $\mathrm{Az}$ országos kezdeményezéseken való részvétel (például Múzeumok Éjszakája, Kulturális Örökség Napok) szintén a közönség bővítését célozza.

\subsection{LÁTOGATÓBARÁT JELZÉSEK}

A megfigyelésekre alapozva kijelenthető, hogy a jelzések (például tárgyfeliratok, információs táblák, tablók) a múzeumok közel $60 \%$-a esetében lá- togatóbarátak. A rossz példák közé tartoznak a túlságosan tárgyakra fókuszáló jelzések, amelyek nélkülözik a személyes történeteket, izgalmas részleteket; a szakmai kifejezésekkel telezsúfolt, túl hosszú leírások; vagy a jelzések teljes hiánya. A jó gyakorlatok között találjuk a megkapó tényeket; a rövidebb, közérthetó formában tálalt leírásokat tartalmazó több táblát/tablót; az „éppen elégséges információt". Az interaktív kiállításokat felvonultató múzeumokra a látogatóbarát jelzések alkalmazása is jellemző, ahogy ez az adatok összehasonlításából látható. Azok a múzeumok, amelyek eredendően már odafigyelnek a szolgáltatásaik és kínálatuk látogatóbarát jellegére, a múködésük több aspektusára is kiterjesztik ezt a gyakorlatot.

\section{A kutatás eredményei - mélyinterjúk}

A kutatás keretében mélyinterjúk készítésére is sor került, amelyek eredményei alapján a következő témák vizsgálhatók.

\subsection{MÚZEUMPEDAGÓGIA}

Fószezonban az iskolás csoportok mindennap igénybe vesznek múzeumpedagógiai foglalkozásokat. Mint kiderült, még a kisebb múzeumokban is, mint az Orvostörténeti Múzeumban, napi szinten tartanak órákat. Ugyanakkor mivel a kis múzeumok látogatói között kevés diák fordul meg, ezen intézmények gyakran panaszkodnak a közoktatási intézményekkel való kapcsolatuk hiányára. A nagyobb múzeumokban, például a Természettudományi és a Mezőgazdasági Múzeumban évi 6-10.000 diák vesz részt ezeken a foglalkozásokon. Népszerú programok közé tartoznak a „pincétől a padlásig” háznéző séták a történelmi épületekben, a kosztümös beöltözések, a csapatjátékok és a kézmúves foglalkozások.

Az intézmények - régóta bevett gyakorlatnak megfelelően - számos különféle múzeumpedagógiai programmal készülnek az állandó és az idôszaki kiállításokra, eltérô korosztályokra fókuszálva, kezdve egészen az óvodás korú kisgyermekekkel. Bizonyos esetekben fogyatékkal éló (például vak) látogatók számára állítanak öszsze programokat. A múzeumvezetők több esetben is azt említették, hogy az interaktív eszközeiket, a játékokat és a beöltözési lehetőségeket a múzeumpedagógiai foglalkozásokra hagyják meg a kiállítások helyett. Igy azonban az egyéni látogatók, például családok vagy azon csoportok, akik foglalkozást nem vesznek igénybe, kiszorulnak az interaktív terekből, amely alacsonyabb 
látogatói élményt eredményezhet számukra. A kiállításokat nem szabadna interaktív és nem-interaktív részre bontani; a tárlat egészében kellene keveredni ezeknek. A szakembereknek fel kell ismerniük, hogy egy kiállításban nem csupán a gyermekek igénylik az interaktivitást, a játékokat és a szórakozást, hanem a felnőttek is. Amenynyiben egy intézmény bóvíteni szeretné a célközönségét, úgy nyújtania kell valamit azoknak az embereknek is, akik kizárólag tanulási célzattal nem keresnék fel a múzeumokat.

\subsection{TÁRLATVEZETÉSEK}

A kiállítások fejlesztésénél fontos szempont, hogy egyénileg is lehet-e őket látogatni, vagy tárlatvezetés szükséges, vagy a látogató szabadon választhat a kettô közül. Kevés olyan intézmény van a 15 között, amely napi szinten egy vagy több tárlatvezetést kínál - a Színháztörténeti Múzeumban 80\%-ban a látogatók kérésére szerveznek túrát, hasonlóan a Zsidó Múzeumhoz és a Magyar Nemzeti Galériához. Néhány múzeumban - különösen az interaktívakban - úgy vélik, hogy a kiállítási tereik nem alkalmasak túrákhoz; a látogatóknak mindenképpen maguknak kell felfedezni a múzeumot. Számos intézmény kizárólag ünnepekhez és fesztiválidőszakhoz kötődő tárlatvezetéseket nyújt, esetleg egy héten egyszer, előre meghatározott időpontban és témáról kínál vezetett túrát. A látogatói visszajelzések többségükben jók, különösen az egyedi tárlatvezetéseket illetően, például amikor az idegenvezető jelmezt ölt vagy detektív játékot játszanak, esetleg tematikus sétát szerveznek a múzeum környékén.

\subsection{MARKETING}

A múzeumok marketing tevékenysége ugyancsak lényeges témakör volt a mélyinterjúkon. Sajnálatos módon nyilvánvalóvá vált, hogy a Ludwig Múzeumon kívül egyik intézmény sem rendelkezik jelentôs éves marketing büdzsével, ami lehetővé tenné számára a tervezést. Az öszszes intézmény azt közölte, hogy nincs vagy csak minimális (évi pár százezer forint) pénze van a marketing kiadások fedezésére. Néhányan közülük új, időszakos kiállításokat vagy rendezvényeket szerveznek pályázati források segítségével, és ezek keretén belül kalkulálnak a marketing költségekkel. A Ludwig Múzeum marketing költségvetése ezzel szemben közel évi 30.000.000 forint, amely már jelentôsebb kommunikációs tevékenységre ad lehetôséget. A múzeumok általában weboldalakat, újságokat, továbbá ingyenes promóciós lehetőségeket használnak, úgymint megjelenés a helyi médiában, valamint ingyenes hirdetési felületeken a különböző kulturális weboldalakon (például http://www.museum.hu/, illetve budapesti programfüzetek) és közösségi portálokon (elsősorban Facebook és YouTube, elvétve említésre került a Twitter és az Instagram is). Sok esetben azonban a social media oldalakat nem hozzák összhangba egymással, vagy csak felületesen menedzselik.

A múzeumok egy része egyébként rendszeresen, különbözó módszerekkel méri a látogatók igényeit: 33\% kérdőívet töltet ki a belépési pontnál vagy a kijáratnál, 33\% rendezvények vagy időszaki kiállítások alatt kérdezi meg óket, a fennmaradó 34\% pedig egyáltalán nem végez semmilyen jellegú kutatást. A kutatás keretében a hallgatói csoportok projektfeladatot is kaptak a múzeumoktól, akik többségében arra kérték őket, hogy végezzenek rövid kérdőíves felmérést a látogatók körében az igényeikre vonatkozóan vagy javasoljanak fiatalokat megcélzó marketingfogásokat.

\section{4. Összefoglalás}

Az elemzés az új muzeológia elveit figyelembe véve készült, ami a múzeumi szakterület egy új paradigmája. Az elmúlt évtizedekben az intézmények funkciója éppúgy változott, mint a feldolgozott témák jellege. A társadalmi kontextus kiemeltté vált, szociális kérdéseket vet fel, amely lehetôvé teszi a párbeszédet és a szélesebb közönség megcélzását. A kiállítások fókuszpontja szintén változott, a tárgyakról az emberekre helyeződött a hangsúly.

A fő kutatási kérdést, így az új muzeológia gondolatának megjelenését a budapesti múzeumok esetén több tényező vonatkozásában vizsgálták a szerzők:

- a kiszélesedő közönséget a látogatószám, a célcsoportok, a marketing tevékenység kapcsán;

- a megváltozott interpretációs módszereket az interaktivitás, a tárlatvezetés, a múzeumpedagógia kapcsán;

- a közérthetóséget a látogatóbarát jelzések kapcsán.

A kutatás rávilágított arra, hogy a megcélzott csoportok többségükben illeszkednek a múzeumi kínálat alapján meghatározható közönséghez; ez azonban sok esetben a szakmabelieket vagy a szenior korosztályt jelenti. Habár szinte minden intézmény nyitna a fiatalok felé, legtöbbjük nem rendelkezik olyan kínálattal, amely e célközönség számára megfelelő volna. A látogatószámot 
négy tényezô kiemelten befolyásolja: központi elhelyezkedés, történelmi épület, általános tematika, interaktivitás. A szerzők feltételezik, hogy amennyiben az említett négy tényezóból kettó teljesül, akkor egy intézmény képes kiemelkedó látogatószám elérésére.

A múzeumok többsége felismeri a modern eszközök szükségességét, de nem engedhetik meg maguknak a fejlesztések megvalósítását, sok esetben azonban a szemléletváltás nem függ az anyagiaktól. A múzeumoknak fontos oktatási szerepük van, amelyet a szórakozva tanulás (edutainment) alapelveinek és a jól megválasztott interpretációs módszereknek a használata nélkül azonban nem tudnak betölteni. A kutatásban résztvevő szinte összes intézmény számos múzeumpedagógiai programot kínál, azt azonban fontos felismerniük, hogy a sikerhez nem elegendô, ha az interaktivitás csak e foglalkozások keretében része a kínálatnak, figyelmen kívül hagyva az egyéni látogatókat.

A múzeumok interaktív berendezéseket inkább időszaki kiállításokon használnak, olyan mértékben, ahogy azt a pénzügyi források, leginkább a pályázatok, lehetővé teszik.

A primer és szekunder adatok elemzése nyomán kiemelt négy, a látogatószámot nagymértékben befolyásoló faktor esetén a jövőben javasolt további részletes, nagyobb mintán végzett kutatást megvalósítani, konkrét hatásuk vizsgálata végett. Egy jövőbeli potenciális kutatást Budapesten és környékén, illetve vidéken teljes körú megkereséssel, valamint nemzetközi környezetben, külföldi intézményeket vizsgálva nagyobb mintán volna érdemes elvégezni. A reprezentativitást biztosító minta elemszámot az elhelyezkedés, a méret és a látogatószám alapján javasolt meghatározni. Tekintettel arra, hogy jelen kutatás nem foglalta magában a fogyasztói oldal felmérését, így az ár-érzékenység, mint a látogatói döntést befolyásoló fontos tényezô nem képezte a vizsgálat tárgyát. Egy jövőbeli kutatás esetén érdemes lenne a felmért intézmények elemzését kiegészíteni ugyanazon múzeumok látogatóinak kvantitatív megkérdezésével.

\section{Köszönetnyilvánítás}

A szerzők köszönettel tartoznak a Pulszky Társaság - Magyar Múzeumi Egyesület segítségéért és közvetítố szerepéért. Köszönetet mondanak továbbá az összes résztvevő múzeumnak, ezek dolgozóinak és menedzsereinek, akik a kutatók rendelkezésére álltak, továbbá a Budapesti Corvinus Egyetem valamennyi hallgatójának, akik a kutatás különböző fázisait lebonyolították.

\section{Felhasznált irodalom}

ÁSVÁNYI K. - BODNÁR D. - JÁSZBERÉNYI M. (2017): Museums of Budapest from the point of view of the experience-desiring cultural tourist. EMOK Conference, Pécs. Publikálás alatt.

BLACK, G. (2005): The Engaging Museum: Developing Museums for Visitor Involvement. Routledge, Abingdon.

BODNÁR D. (2015): Place of modern devices in museums, through the case study of the Virtual Archaeological Museum of Herculaneum. In: Regional Studies Association Tourism Research Network Workshop: Metropolitan Tourism Experience Development. Corvinus University of Budapest, Budapest. pp. 178-188.

BODNÁR D. - JÁSZBERENYI M. - FEHÉR ZS. (2015): Museum in Motion. EUGEO Conference, Budapest.

DCMS (Department of Culture, Media and Sport) (2006): Understanding the Future: Priorities for England's Museums. DCMS, London.

HOOPER-GREENHILL, E. (2000): Museums and education: purpose, pedagogy, performance. Routledge, Abingdon.

HUDSON, K. (1977): Museums for the 1980s: A survey of world trends. UNESCO/Macmillan, Paris and London.

FEHÉR ZS. (2014): Ludwig Museum - Citadel of contemporary art. In: Jászberényi M. (ed.): Variegation of cultural tourism. Nemzeti Közszolgálati és Tankönyv Kiadó, Budapest. pp. 261-272.

KIRSHENBLATT-GIMBLETT, B. (1998): Destination Culture. Tourism, Museums, and Heritage. University of California Press, Berkeley.

KREPS, C. (2009): Indigenous curation, museums, and intangible cultural heritage. In: Smith, L. - Akagawa, N. (eds.): Intangible Heritage. Routledge, Abingdon. pp. 193-208.

McCALL, V. - GRAY, C. (2014): Museums and the 'new museology': Theory, practice and organisational change. Museum Management and Curatorship. 29. 1. pp. 19-35.

MOORE, K. (1997): Museums and Popular Culture. Cassell, London.

PACKER, J. - BALLANTYNE, R. (2002): Motivational factors and the visitor experience: A comparison of three sites. Curator. 45. 3. pp. 183-198.

SANDELL, R. (2007): Museums, Prejudice and the Reframing of Difference. Routledge, Oxon.

SIMPSON, M. (1996): Making Representations: Museums in the Post-Colonial Era. Routledge, London.

SMITH, M. K. (2003): Issues in Cultural Tourism Studies. 2nd edition. Routledge, London. 
TOMIUC, A. (2014): Navigating culture. Enhancing visitor museum experience through mobile technologies. From Smartphone to Google Glass. Journal of Media Research. 7. 3. pp. 33-47.
VERGO, P. (1989): The New Museology. Reaktion Books, London.

WALSH, K. (1992): The representation of the past: museums and heritage in the post-modern world. Routledge, London. 